\title{
慢性血液透析患者の腹部超音波検査
}

\author{
浅田 学 鈴木良一関根智紀* \\ 河本 真 美* 村上 信 乃** 伊良部 徳 次** \\ 旭中央病院内科 同超音波検査室 ${ }^{*}$ 同透析センター** \\ (昭和 59 年 8 月 25 日受付)
}

key words：慢性血液透析，超音波検査，CT, 後天性腎囊胞，腎癌

〈要旨〉

長期透析中の患者の腎にみられる後天性の腎囊胞と, これに高率に合併すると言われる腎癌の診断にはX線 CT が 有用とされているが, 超音波検査の有用性に関する報告は殆どみられない。一方われわれは日常診療において, 腎癌 や腎囊胞の診断には超音波検査が非常に有用と考え, 超音波検査を従来のX線検査に代る第 1 選択の検査法としてい る.

今回われわれは, 慢性透析患者 94 例を対象に腎癌, 腎囊胞などのスクリーニングを目的とした腹部超音波検査を施 行, 単純 $X$ 線 $C T$ 検査との比較も行い, 以下の結果を得た。

超音波検査では著しい萎縮腎を除く殆どの腎（97\%）が描出可能であった。腎囊胞の診断能は CTより超音波検査 がすぐれていた。超音波，CT 両者で全体の $44.2 \%$ 多発性囊胞，11.6\%に単発性囊胞の合併が診断された。襄胞の 合併率は透析期間が長いほど高率となり，2 年未満で $41.4 \%, 2$ 年以上 4 年末満で $48.1 \%, 4$ 年以上 6 年未満で $66.6 \%, 6$ 年以上では $83.4 \%$ の合併率であった。超音波検査で 2 例の腎癌が診断されたが, このうち 1 例はCTでの 診断は困難であった。腎の石灰化病変の診断には CT がすぐれており, 超音波検査では診断不能例が多かった。 3 例 の襄胞内出血が超音波検査および超音波ガイド穿刺で診断された。超音波検査では腎以外の病変として, 11 例の胆石症 をはじめ, 肝囊胞 4 例, 肝腫大, 脾腫各 4 例, 胸水 2 例, 腹水 1 例, 兴の他肝静脈下大静脈の拡張が診断可能であっ た.

以上の結果と超音波検査の簡便性, 非侵襲性, 経済性などを考え合せると, 透析患者の腎囊胞, 腎癌をはじめ各種 疾患の画像診断に際しては, 超音波検査を第 1 選択とすべきと考える. さらに, 透析開始前より慢性腎不全患者の腹 部超音波検査を定期的に行うことは, 霊胞や腎癌など腎病変の早期発見はもちろん, 腎不全の病態の総合的な把握に も有用であると考える。

\section{Abdominal ultrasonography in long-term dialysis patients}

Manabu Asada, M. D., Ryoichi Suzuki, M. D., Tomoki Sekine*, Mami Kawamoto*, Shino Murakami, M. D.**, Noritsugu Irabu, M. D.**

Department of Internal Medicine, Ultrasonography Center*, Kidney Center**, Asahi General Hospital. Asahi City, Chiba

It is generally held that computed tomography (CT) is useful in diagnosing acquired renal cyst in long-term dialysis patients, as well as renal cancer, which very often follows as a complication. Few cases in which ultrasonography (US) works for that purpose have been reported. But we believe that US is highly useful in diagnosing renal cancer and renal cyst and have been using the technique as the first alternative to conventionai $\mathrm{X}$-ray examination.

We performed US on 94 long-term dialysis patients for the screening of renal cancer and renal cyst and compared the results with those from CT. Our findings are as follows.

浅田 学 旭中央病院内科

干 289-25 旭市イの 1326 (04796-3-8111) 
With US, most kidneys ( $96.8 \%$; with the exception of very contracted kidneys) were successfully pictured. Renal cysts were better diagnosed by US than by CT. With US and CT together, multiple cysts were diagnosed in $44.2 \%$ of all patients and solitary cyst was noted as a complication in $11.6 \%$. The longer dialysis had been performed, the higher the cyst complication rate was : $41.4 \%$ when dialysis was performed for less than 2 years ; $48.1 \%$ for $2-4$ years ; $66.6 \%$ for $4-6$ years ; $83.4 \%$ for 6 years and longer. With US, two cases of renal cancer were diagnosed, but one of them could not be diagnosed with CT. CT provided a better diagnosis of calcification, most of which could not be diagnosed by US. Three cases of intracystic hemorrhage diagnosed by US and US -guided puncture.

Besides renal lesions, US also provided successful diagnosis of 11 cases of cholelithiasis and 4 cases of liver cysts, hepatomegaly and splenomegaly, 2 cases of pleural effusion and 1 case of ascites, some cases of dilatation of the hepatic vein and inferior vena cava.

Considering the above results and the ease, noninvasiveness, economy of US, we believe that US should come first in diagnosing abdominal disease, including renal cyst and cancer in dialysis patients. We also believe that regular abdominal ultrasonography preformed on patients with chronic renal disease even before dialysis is started will be effective in gaining an overall understanding of chronic renal failure.

\section{緒言}

われわれの病院では 1979 年より,リニア電子スキャン による腹部超音波検查を開始, 1984 年 6 月までに延べ約 19,000 件の検査を行っている。当初は胆石症の診断を主 なる目的に行った検査であったが，徐々に検査の対象が 拡がり, 現在では腎臓もルーチンの検查対象となってい る.この間非常に多くの泌尿器科的な腎疾患が診断され, 超音波検查は, 腎癌をはじめ各種腎疾患の検索において, 従来のX線検査にかわる第 1 選択の検查法として定着し ている，われわれは超音波検查開始直後より，腹痛など で検査に回って来た透析中の患者の腎臓に, 多数の囊胞 が見られることが多いのに気づいていたが，それらを先 天的な腎囊胞と考えていた。しかし最近になって，長期 透析患者の腎臟に，後天的な霊胞が合併すること，かつ
腎癌の合併も高頻度にあることを知った ${ }^{1 \sim 5)}$. 従来，腎臓 特に透析中の腎の画像診断としてはX線 CT (CT) の有 用性は数多く報告されているが，超音波検查に関するも のは少ない ${ }^{6 \sim 12)}$ 。われわれは, 後天性腎囊胞, 腎癌, その 他腎および腎臓以外の腹部疾患のスクリーニング法とし ての超音波検查の有用性を知る目的で, 当院透析セン ターで透析中の患者全例を対象に腹部超音波検查を行っ た。さらに数カ月後 CTも行ったので, 両者を適宜対比 しつつ検查成績を報告したい.

\section{対象・方法}

対象は, 旭中央病院透析センターで慢性血液透析を受 けている男子 58 例, 女子 36 例の計 94 例。年齢は $20 \sim 76$ 歳 (平均 45.8 歳), 透析期間は 1 力月 10 年 (平均透析 期間 44 力月). 原疾患は慢性系球体腎炎 77 例, 悪性高血

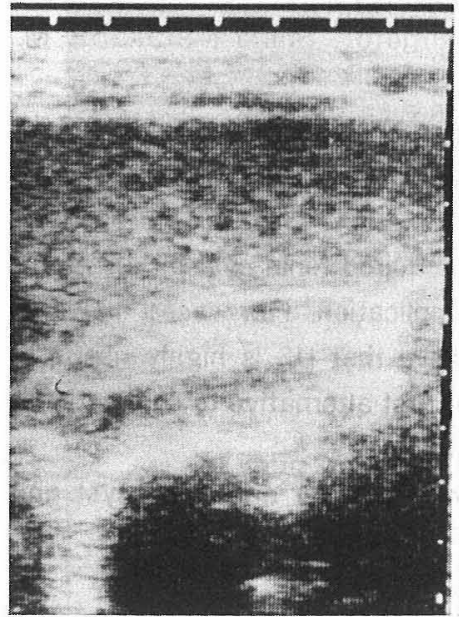

図 1-a 右腎超音波像

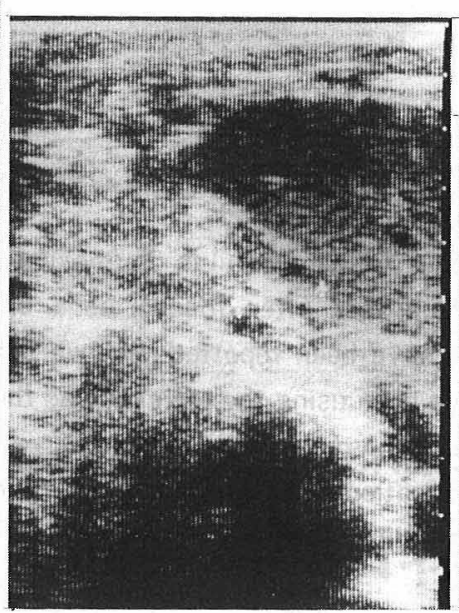

図 $1-b$ 左腎超音波像

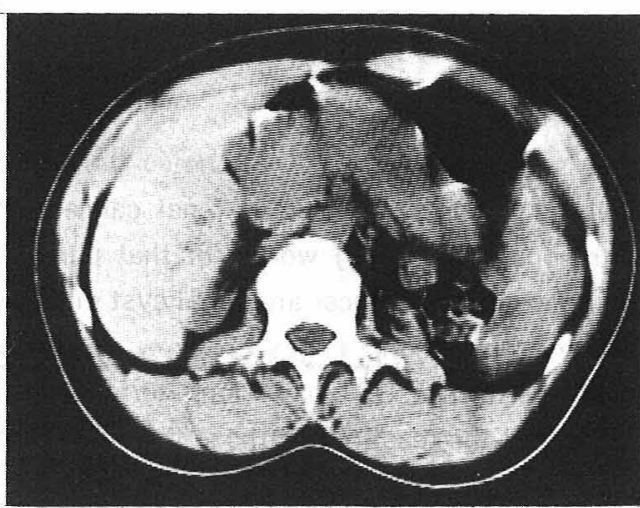

図 1-c CT 像

図 1 著しく萎縮した腎の超音波像と CT 像。左腎は超音波検查では描出困難（b) 
圧 3 例，糖尿病 3 例，先天性多発囊胞腎 7 例，その他 4 例。

全例を対象に，腎臓の描出能と腎の萎縮あるいは腫大 の有無, 腎癌の診断の可能性, 腎の石扊化等の診断の可 能性を検討。先天性多発囊胞腎と腎結核（水腎症）の 8 例を除く 86 例において, 合併囊胞の診断能および囊胞の 合併率と透析期間の関係を検討した。また全例における 腎臓以外の病変, すなわち胆石症, 肝脾腫などの発見の 可能性を検討した。

検查は，昼間透析後ないし夜間透析前に，特別の前処 置はしないで施行した。なお CT は単純 CT のみ行っ た。

検查に使用した診断装置は, 東芝 SAL 30A リニア電 子走查型超音波診断装置で探触子は周波数 $3.5 \mathrm{MHz}$ を 使用した。CT は東芝 TCT 80A および日立 CTW3 の いずれも第 3 世代の装置である。

\begin{tabular}{c|c|c|c|c}
\hline US & 多発囊胞 & 単発囊胞 & 賈胞なし & 計 \\
\hline 多発囊胞 & 23 & 3 & 1 & 27 \\
\hline 単発囊胞 & 1 & 5 & 0 & 6 \\
\hline 囊胞なし & 10 & 5 & 38 & 53 \\
\hline 計 & 34 & 13 & 39 & 86 \\
\hline
\end{tabular}

表 1 超音波と CT による腎囊胞の診断

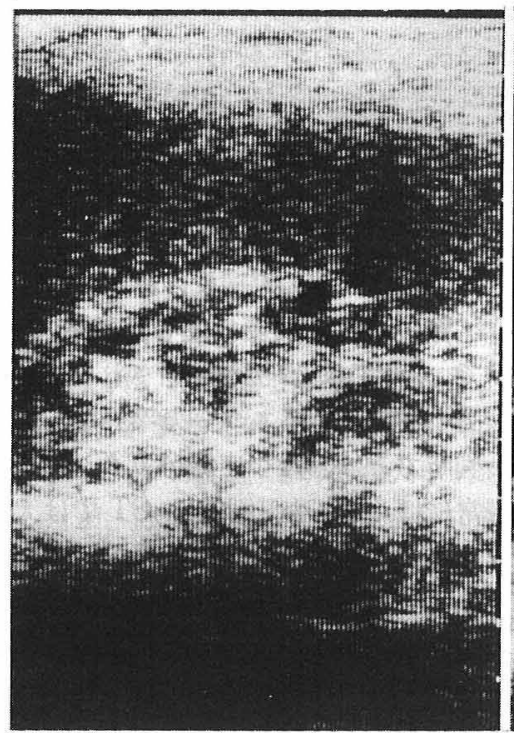

図 2-a
結果

1. 腎の描出能と腎の大きさ

超音波検査では対象 94 例，185 腎 (片腎摘出後 3 例) のうち，179 例 (96.8\%) は描出しえたが両腎描出不能の 1 例と左腎 3 例右腎 1 例の計 6 腎 $(3.2 \%)$ は描出不能で あった。CT では全例で腎の描出が可能であった。超音 波検査で描出不能な症例は，CT 像ではいずれも萎縮の 著しい腎であった(図 1 )。左右の腎の超音波像を比べる と，右腎は比較的明瞭に描出されることが多かったが， 左腎の超音波像は不明瞭なものが多い傾向があった。

先天性囊胞腎 7 例，水腎症を呈した腎結核 1 例，囊胞 と腎癌を合併した 1 例，その他囊胞を合併した 1 例，計 10 例 (10.6\%) の腎は腫大していたが，84例 (89.4\%) においては，腎は囊胞の合併の有無にかかわらず萎縮し ていた。

\section{2。囊胞の診断（表 1 ）}

超音波検査では対象 86 例中 34 例の多発性囊胞が，ま た 13 例の単発性囊胞が診断されたが, CT ではそれぞれ 27 例と 6 例が診断されるにとどまった. CTで診断され 超音波検査では診断不能だったのは 1 例のみであった が，超音波検查で診断されながら CTでは診断不能のも のは 15 例と多かった。両検查を合せると 86 例中 38 例 $(44.2 \%)$ に多発性囊胞が，10例 $(11.6 \%)$ に単発性囊 胞の合併が診断された。

透析患者の腎にみられる囊胞は，通常みられる腎囊胞 より小さく，やや不整形にみえるものが多いようであっ

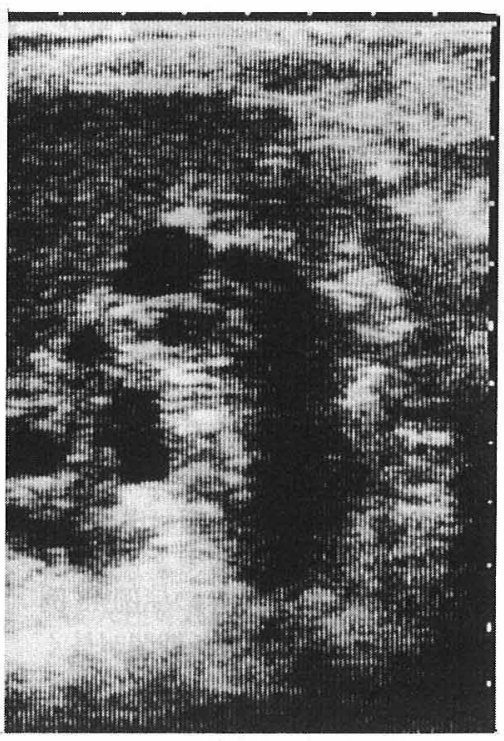

図 2-b

図 2 慢性透析患者に合併した腎囊胞の超音波像。小囊胞の少数合併例 ( a ) とやや大きな囊胞の多数合併例（b） 


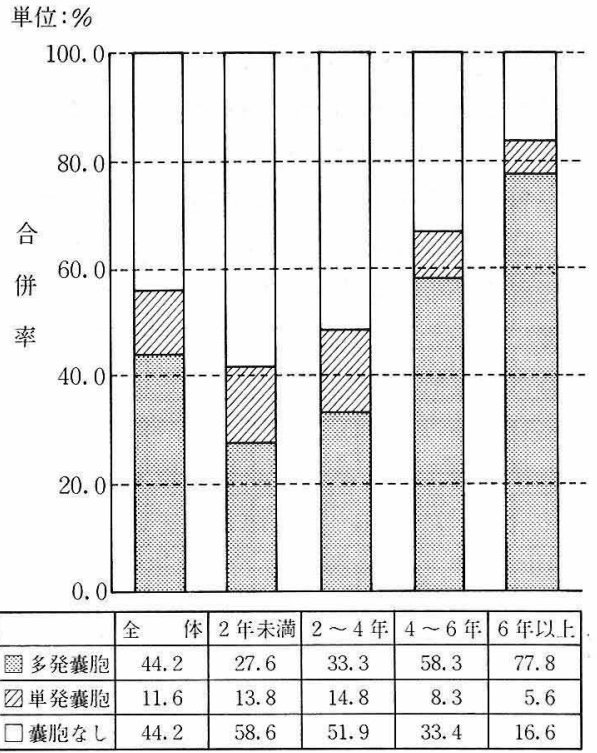

図 3 透析期間と囊胞合併率の関係

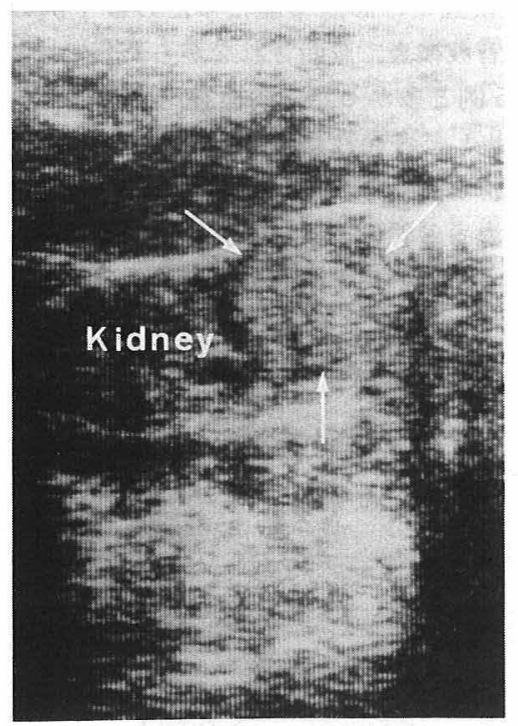

図4 第 1 例の腎癌の超音波像。この像では囊胞の 合併は不明

た（図 2).

3. 囊胞の合併と透析期間の関係（図 3 ）

囊胞の合併は透析開始後 1 力月より 10 年の症例 48 例 (55.8\%) にみられた。囊胞の合併率は透析期間が長? なるほど高頻度となり，2 年末満で $41.4 \% ， 2$ 年以上 4 年未満で $48.1 \%, 4$ 年以上 6 年未満で $66.6 \%, 6$ 年以上 では 83.4\%に囊胞の合併がみられた。

囊胞合併例の平均透析期間は 52.4 力月, 非合併例の平

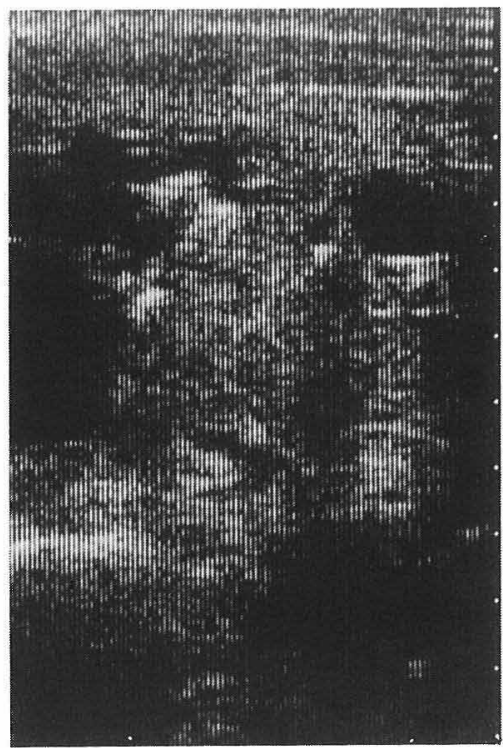

図 5 第 2 例の腎癌の超音波像。囊胞にかこまれる ように腫瘤像が見られる

均透析期間は 30.3 カ月であった。

なお抢囊胞合併例の検查時の平均年齢は 44.5 歳, 透析導 入時の平均年齢は 40.3 歳であり, 囊胞非合併例の検査時 の平均年齢は 46.3 歳, 透析導入時の平均年齢は 43.4 歳 であった。

\section{4. 腎癌の診断}

超音波検查で 2 例の腎癌が発見された。第 1 例は透析 期間 2 年 6 カ月の 48 歳男性で腎には少数の小囊胞が合 併していた(図 4 ).第 2 例は透析期間 8 年 5 力月の 40 歳 男性で, 腎には比較的大きな囊胞が多数みられた(図 5 ). 2 例とも比較的早期の腎癌であり根治手術が可能であっ たが，第 2 例にはその後IIb 型早期胃癌の合併も発見さ れている.CTでは第 2 例の腎癌の診断が困難であった。 またCTで新たに発見された腎癌はなかった。

5。その他の腎病変の診断

腎の石灰化病変は超音波検查では 7 例のみ診断可能 で, CT では 35 例が診断された。萎縮しエコーレベルの 高い腎内の，高エコーの部分を石灰化病変であるか否か 判断するは困難な症例が多く，超音波検查の診断能は非 常に低くなった（図 6).CTでは大動脈の石灰化も同時 にみられる症例が多く, 腎の石灰化病変も大部分は動脈 の石灰化と思われた(図 7 )。超音波検査で 3 例の囊胞内 出血が診断された。いずれも先天性囊胞腎の囊胞内出血 であった。囊胞の内部エコーが均一にやや高いことより 囊胞内出血と診断，超音波ガイドで穿刺を行い，血液を 吸引し確診を得た。

6. 腎外病変の診断 


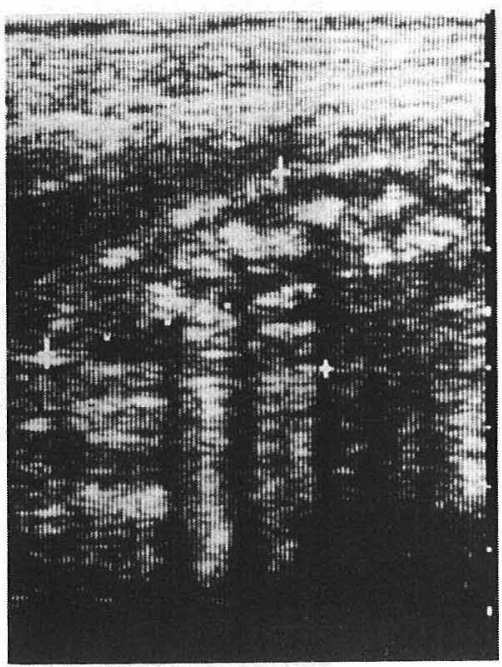

図 6-a

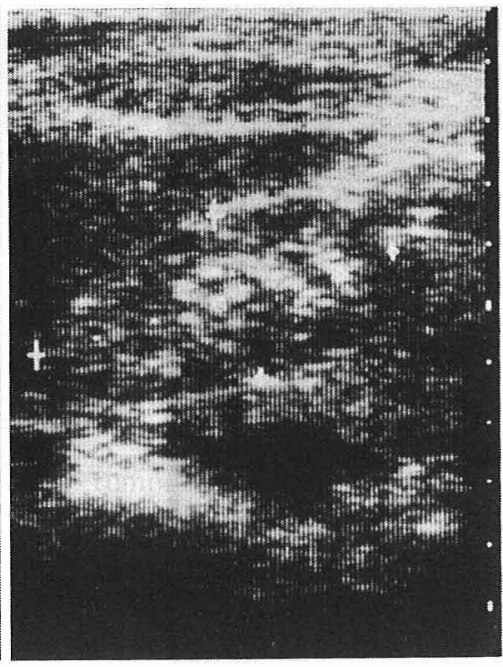

図 6-b

図 6 腎の石灰化病変の超音波像 ( a ). 石灰化のない腎 (b) との違いは音 響陰影の有無のみで, 鑑別は困難

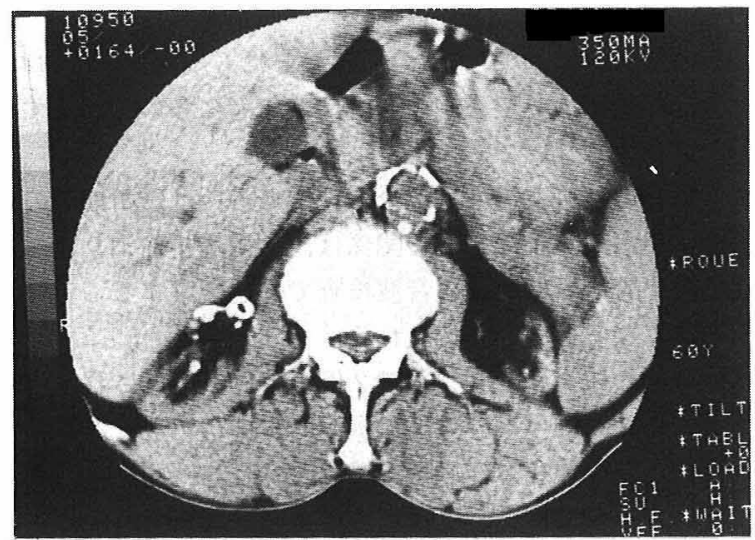

図 7 石扊化病変の CT 像. 大動脈の高度の石灭化が みられる

超音波検査では腎以外の病変として, 胆石症 11 例, 肝 囊胞 4 例, 肝腫, 脾腫各 4 例, 胸水 2 例, 腹水 1 例など が診断された(図 $8 ， 9$ )。肝囊胞 4 例のうち 3 例が先天 性囊胞腎に合併したものであった。肝と脾の腫大は明瞭 なものは 4 例であったが, 腫大傾向のものはさらに多 かった。また，下大静脈と肝静脈の拡張傾向をみる症例 も多かった。

\section{考案}

透析療法の進歩と普及により, 腎不全患者の長期生存 例が増加してきた。一方慢性腎不全の腎に後天性の囊胞 が合併し，腎癌の合併率も高いことが知られ，透析患者 の管理のうえで重大な問題となってきた ${ }^{1 \sim 12)}$.
従来，腎囊胞や腎癌などの診断には排泄性腎孟造影が 用いられてきたが，最近のCT と超音波検査の進歩によ り, 腎の占拠性病変の非侵襲的な画像診断が可能となつ てきた。われわれは検査の簡便性と診断能の高さより, 超音波検査を腎の画像診断の第 1 選択の検査法と考えて おり，腎癌の診断においても高成績を得ている ${ }^{13)}$ 。一方慢 性腎不全患者の腎の画像診断にCT を用いた報告は多い が超音波検查に関するものは少ないようである ${ }^{6 \sim 12)}$.こ れは各施設において CT の有用性がより早く知られたた めの結果であり, 超音波検查と CT の有用性の比較によ る選択の結果ではないようで，この時期に超音波検査の 有用性を明らかにしておくことは意味のあることと考え る。

萎縮してエコーレベルの高くなった腎臓を，超音波検 查により明瞭に描出することは困難であるうと予想され た。今回のわれわれの成績では，対象 185 腎のうち 6 腎 (3.2\%) は描出不能であったが 179 腎 $(96.8 \%)$ は描出 可能であり，数字の上では予想以上の成績であった。し かし，肝臟を音響空にして走查できる右腎に比べ，左腎 の描出は難しく，得られた超音波像も右腎に比べると不 明膫なものが多かった。腎臓の描出能が高かった理由に， 後天性腎囊胞の合併があげられる。すなわち, 超音波検 查で描出しやすい囊胞の存在することにより，不明瞭な 超音波像からも腎臓を認識しえた例も多かった。超音波 検查で描出できなかった 6 腎は CT 像では, 著しく萎縮 し囊胞の合併もみられない症例であった。

透析患者の腎には，囊胞の合併とともに腫大傾向を示 


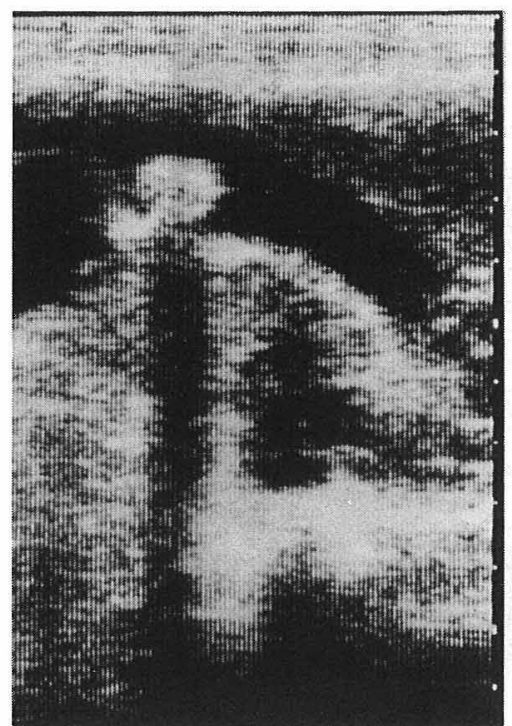

図 8 胆囊胆石症の超音波像。音響陰影を伴う胆石 が胆囊内にみられる

すものも多いと言われている7,8). しかしわれわれの成績 では, 先天性囊胞腎の症例以外で囊胞を合併し腫大した 症例は, 腎癌を合併した 1 例を含めわずか 2 例のみで あった。超音波像から腎臓の体積を求めることは困難で あり, 長軸と短軸の最大径により腎の大きさを判定した が, 腎の最大径が探触子の長さ $(80 \mathrm{~mm})$ 以下の症例が 多かった。

超音波検査と CT の両者で, 対象 86 例中多発性囊胞 が 36 例, 単発性囊胞が 10 例, 計 46 例が診断された。こ のうち超音波検査で診断しえなかったのは 1 例のみで あったが, CT では 15 例が診断不能であり, 囊胞の診断 においては超音波検查が明らかにすぐれていた。これは 超音波検査が囊胞性病変の描出にすぐれているのに加 え, 実時間表示でいろいろな方向からの走査が可能であ るのに対し, CT では小囊胞が呼吸性移動や partial volume effect などにより不明瞭となるためと考えられる。

囊胞の合併は 86 例のうち 48 例 (55.8\%) の多数にみ られ, 合併率は透析期間が長くなるほど高頻度であった。 しかしわれわれは, 透析療法を受けていない慢性腎不全 の数例にも透析患者と同樣の多発性腎囊胞をみている し，他にも同様の報告がみられる と囊胞の合併率の関係は, 血液透析そのものを囊胞の原 因とする以上に，腎不全の期間の長さと囊胞の合併が関 係することを示唆するものとも考えられる。

囊胞合併例と非合併例では, 超音波検查時おるび透析 導入時のいずれにおいても囊胞合併例の平均年齢が若 かった。透析患者の年齢は, 透析導入時のその施設の透

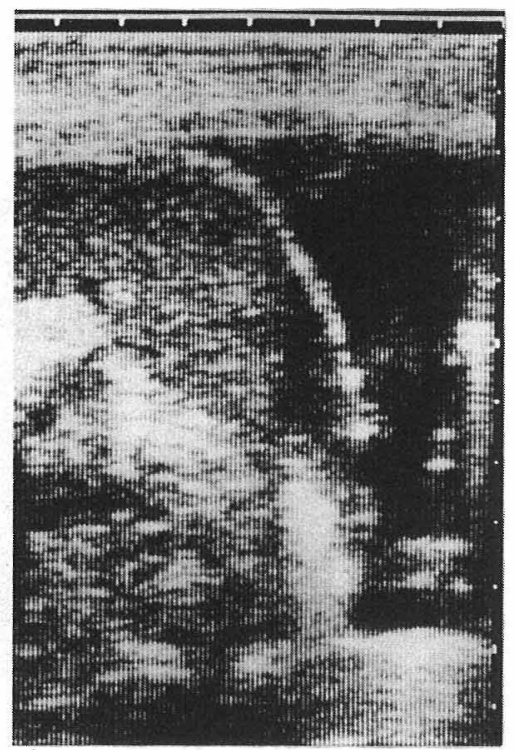

図 9 左側胸水の超音波像。脾臓の上に隔膜の高工 コーに接して胸水による無（低）エコーの部 分がみられる

析療法の適応基準, 患者の予後などにも規定されており, 今回の結果のみで囊胞の合併は若年者に多いと結論する ことはできないであろう。

囊胞の合併と慢性腎不全の期間あるいは透析期間の長 さ, 患者の年齢などとの関係は, 今後透析前より慢性腎 不全の腎の形態を, 超音波検查で経過観察することで明 らかになるものと考えられる。

今回のスクリーニングで 2 例の腎癌が発見された。い ずれも比較的早期の腎癌で根治的手術が可能であり, 術 後約 1 年の現在も経過順調で, 透析療法を継続中である. 慢性腎不全に合併した後天性囊胞には腎癌のみならず良 性の腺腫も合併することが知られている。我々の 2 例の 腎癌においても, 摘出された腎には顕微鏡的に複数の腺 腫の合併がみられた。この腺腫を前癌状態と考えるべき か，良性の腺腫が超音波検査あるいは CT で腎癌と鑑別 可能かなどは，今後に残された問題である.

囊胞内出血が 3 例発見されたが，いずれも先天性囊胞 腎にみられた，無症候性の小出血であった。超音波検査 による囊胞内出血の診断は比較的容易であった。囊胞内 出血と鑑別すべきものとして膿瘍と腫瘍が考えられる が, 超音波ガイドの穿刺で鑑別が可能である。この他に もわれわれは, 大量の出血と疼痛を伴い腎摘を余儀なく された囊胞内出血を 2 例経験しているが，いずれにおい ても超音波検査が他の疾患との鑑別に有用であった。

萎縮しエコーレベルが高くなった腎の, 石灰化病変の 超音波検査による診断能は低かった。これに比べ, CTで 
は小石灰化病変も良く描出されていた。

超音波検查では, 腎のみでなく腹部全体の同時検索が 可能である.その結果, 胆石症をはじめ多くの腎外病変 が診断された。

胆石症が 11 例 (11.7\%) に発見されたが，われわれの 施設に拈ける胆石症の診断率が $10.8 \%(1,691 / 15,665)$

であるのにくらべ有意に高い合併率とはいえない。透析 患者の胆石症発作は時々経験されるし, その診断には超 音波検査が最も有用である.

明らかな肝腫と脾腫が各 4 例診断されたが，そのほか にも腫大傾向の症例がみられ, 下大静脈と肝静脈の拡張 例や, 胸水, 腹水などもみられた。これらは透析患者の 全身状態, 特に心機能と循環血液量に関係あるものと考 えられる。非侵襲的な心機能の判定には UCG が有用で あるが，Mモード併用の可能な機種を使用すれば，腹部 超音波検查と同時に UCG も可能となる。

以上，超音波検査の有用性を中心に述べたが，萎縮し た腎の描出, 石灰化病変の診断においては CT が明らか にすぐれていた。

CT でも腎と肝，脾などの同時検索は可能である。し かし検査の簡便性においては超音波検査がはるかにま さっている，われわれは，まずスクリーニング検査とし て超音波検查を行い, その結果必要な症例に限り CTを 行うことが実際的であろうと考えている.

今後, 慢性腎疾患患者の腹部超音波検查を, 透析開始 前より定期的に行うことが, 囊胞や癌の診断のみならず, 慢性腎不全の病態の総合的な理解に役立つものと考え る。

\section{結語}

慢性血液透析患者の腹部超音波検査を行い, 後天性腎 囊胞や腎癌の診断における有用性を確認した。診断能の 高さ，簡便性，非侵襲性，経済性などを考えると，慢性 腎不全の腹部画像診断に扔いては, 超音波検査を第 1 選 択の検査法とすることが妥当であると考える.

本論文の要旨は第 29 回人工透析研究会総会 (ワークショッ プIV 透析患者の画像診断）において発表した。

\section{文献}

1) Dunnill, M. S., Millard, P. R., Ogiver, D. : Acquired cystic disease of the Kidney : a hazard of long -term intermittent maintenance haemodialysis. J. Clin. Path., 30 : 868-877, 1977.

2) Feiner, H. D., Katz, L. A., Gallo, G. R. : Acquired cystic disease of kidney in chronic dialysis patients. Urology, 17 : 260-264, 1981.

3）北田博久, 栗原 怜, 鈴木志寿子, 尾内善五郎, 由 利健久, 石川 勲, 篠田 晤：腎癌の発生をみた“acquired cystic disease of the kidney”の一例. 日腎 誌, 11：1145-1155，1979.

4) Konishi, F., Mukawa, A., Kitada, H. : Acquired cystic disease of the kidney and renal cell carcinoma on long term hemodialysis. Acta Pathol. Jpn., $30: 847-858,1980$.

5) Fayemi, A. O., Ali, M. : Acquired renal cysts and tumors on chronic primary kidney diseases. Path. Res. Pract., 1968 : 73-83, 1980.

6) Bommer, J., Waldherr, R., Van Kaick, G., Strauss, L., Ritz, E. : Acquired renal cysts in uremic patients - in vivo demonstration by computed tomography. Clin. Nephrol., 14 : 299-303, 1980.

7）長谷川弘一, 小田初夫, 聴濤貴一郎, 松下義樹, 井 上喬之, 井上 隆, 森口英世, 大西康夫, 岡本輝夫, 森井浩世, 和田正久: 慢性血液透析患者の腎 CT 所 見と臨床像について. 腎と透析, $14: 445-450,1983$.

8）石川 勲：長期透析患者にみられる多のう胞化萎縮 腎と腎癌. 透析会誌, $15 ： 442,1982$ 。

9) 上村 旭, 出口隆志, 田尻正記, 湯浅保子, 酒井信 治, 鈴木正司, 高橋幸雄, 今井久弥, 平沢由平, 森 田 俊: 長期透析患者の後天性腎のう胞について。 透析会誌, $15 ： 442-443,1982$.

10）井上 篤, 中村義弘, 三戸康義, 小倉三津男, 有輪 六郎：多のう胞化萎縮腎と腎癌の発生について一当 施設での長期透析例の検討一. 透析会誌, $15 ： 443$, 1982.

11）川野恵三, 宗 正敏, 森下 茂, 宇野英明, 前田孝 夫, 湯川 進, 野本 拓, 近藤一美, 永栄正好, 田 伏俊作, 宅田 弘, 奥田林三郎, 西出 厳: 長期透 析患者の残存腎の悪性化の示標一腎 CT 所見を中心 として. 透析会誌, $15: 443-444,1982$.

12) Levine, E., Grantham, J. J., Slusher, S. L., Greathouse, J. L., Krohn, B. P. : CT of acquired cystic kidney disease and renal tumor in long-term dialysis patients. AJR, 142 : 125-131, 1984.

13）浅田 学, 山口 一, 鈴木良一, 関根智紀, 河本真 美：腎癌の超音波診断. 日超医論文集, $41 ： 677-678$, 1982 . 